\title{
Gunnar Karlsson
}

\section{Drög að réttarsögu orðlistar á Íslandi}

Í pessari grein eru dregnir saman helstu vitnisburðir um réttarreglur, bæði lög og óformlegar siðareglur, um skáldskap og aðra texta á norrænu málsvæði á fyrstu öldum Íslands byggðar og er efninu pó fylgt eftir jafnvel fram á 20. öld ef tilefni virðist til. ${ }^{1}$ Sögusviðið er einkum íslenskt miðaldasamfélag, og er par talinn með starfsvettvangur íslenskra skálda og sögumanna sem gat náð austur til Svíbjóðar og suður til Danmerkur og Englands, ef sögum er trúað. Pessar reglur reynast falla í tvo meginflokka sem mynda allt að pví andstæður. Annars vegar eru reglur um eignarrétt höfunda á textum og fordæming á ritstuldi, hins vegar hömlur við flutningi texta, einkum peirra sem voru líklegir til að móðga, særa eða skaða. Segja má að annars vegar séu reglur til verndar orðlistinni, hins vegar reglur til verndar fólki gegn henni.

Lítið hefur verið fjallað um petta efni áður. Í registursbindi Kulturbistorisk leksikon for nordisk middelalder finnast ekki orðin forfatter, forfatterret, böfundur, höfundarréttur, injurie eða ophavsret. Orðin fullrétti, fullréttisorð, hálfrétti, hálfréttismenn og hálfréttisorð, sem vísa til pess sem við köllum meiðyrði, koma nokkrum sinnum fyrir en ekki sem uppflettiorð. ${ }^{2}$ Í nýjustu og mestu bókmenntasögu okkar Íslendinga, Íslenskri bókmenntasögu I-V sem Mál og menning gaf út á árunum 1992-2006, eru engar efnisorðaskrár, en efnisyfirlit bindanna vísa ekki á neitt um réttarreglur um bókmenntir. ${ }^{3}$

1 Ég pakka fyrir gagnlegar ábendingar ritrýna undir nafnleynd og sömuleiðis ritstjóra heftisins.

2 Kulturhistorisk leksikon for nordisk middelalder fra vikingetid til reformationstid XXII, Register, Reykjavík: Bókaverzlun Ísafoldar, 1978, bls. 30, 32, 40, 49, 51, 83. Uppsláttarorð eru einkennd pannig í registrinu að dálknúmerið er með skáletri.

3 Íslensk bókmenntasaga I, Vésteinn Ólason ritstjóri, Reykjavík: Mál og menning, 1992, bls. 7-9; II, Vésteinn Ólason ritstjóri, Reykjavík: Mál og menning, 1993, bls. 5-7; III, Halldór Guðmundsson ritstjóri, Reykjavík: Mál og menning, 1996, bls. 5-8; IV, Guðmundur Andri Thorsson ritstjóri, Reykjavík: Mál og menning, 2006, bls. 5-8, V, Guðmundur Andri Thorsson ritstjóri, Reykjavík: Mál og menning, 
Hér er pví farið inn á nánast ókannað svið. Við pær aðstæður fannst mér vænlegast að tína saman sem mest og fjölbreyttast efni eftir pví sem kunnátta leyfir. En óhjákvæmilegt er að árangurinn verði samtíningur og samhengi hans í veikasta lagi. Orðið „drög“ í fyrirsögn greinarinnar ber að taka alvarlega. Ósvarað er hvers vegna práður rannsóknarinnar nánast slitnar í sundur á tímabilinu frá síðmiðöldum til 19. aldar, einnig hvort meginpættirnir tveir, eignarréttarvernd orðlistar og vörn gegn orðlist, eiga eitthvað markvert sameiginlegt. Lögfræðilega staðalritið um pessi efni í íslensku samfélagi er bók Páls Sigurðssonar, Höfundaréttur frá 1994. Hún fjallar einkum um gildandi rétt, að vísu með inngangi um réttarpróun á pessu sviði síðan í klassískri fornöld. En á Íslandi rekur Páll söguna ekki lengra til baka en til 19. aldar. Grein mín skarast pví aðeins um fáa áratugi við bók Páls. ${ }^{4}$ Nokkurn almennan fróðleik um höfundarrétt á Íslandi á 20. öld má einnig sækja í tvær greinar í Tímariti lögfreðinga eftir Sigurð R. Pétursson og Pórð Eyjólfsson. ${ }^{5}$ Í engu pessara rita er drepið á höfundarrétt á blómaskeiði orðlistar á Íslandi á miðöldum. Hina hlið pess máls sem hér verður rakið, hömlur við kveðskap, ræðir Gunnar Thoroddsen ásamt annarri meiðyrðalöggjöf í doktorsritgerð sinni, allt frá Grágásarlögum til samtímans. Par er einnig yfirlit yfir löggjöf um ærumeiðingar í sex nágrannalöndum okkar. ${ }^{6}$

Pótt hér sé farið inn á lítt kannað svið munu lesendur sem eru vel að sér í íslenskri miðaldabókmenntasögu finna margt sem peir pekkja vel fyrir. Hér reynast skipta máli sumar bekktustu staðreyndir hennar. En ætlun mín er að setja pær í nýtt samhengi í pví skyni að vekja lesendur til umhugsunar um réttarstöðu sagna og kvæða á Íslandi á miðöldum og lengur.

2006, bls. 5-8. Раð eina sem virðist koma nærri pessu efni samkvæmt efnisyfirlitum er kaflafyrirsögnin „Krafan um málfrelsi tilfinninganna“, en pað reynist vera yfirlit Silju Aðalsteinsdóttur um nýrómantískan skáldskap á fyrri hluta 20. aldar, frá Stefáni frá Hvítadal til Tómasar Guðmundssonar. - Islensk bókmenntasaga IV, bls. $125-189$, sbr. bls. 4.

4 Páll Sigurðsson, Höfundaréttur. Meginreglur islensks réttar um böfundarvernd, Reykjavík: Háskólaútgáfan, 1994, bls. 15-39.

5 Sigurður R. Pétursson, „Nokkur orð um lögvernd höfundaréttar“, Tímarit lögfreðinga IV/1954, bls. 132-144; Pórður Eyjólfsson, „Um höfundarétt“, Tímarit lögfreðinga $\mathrm{VIII}(2) / 1958$, bls. 49-75.

6 Gunnar Thoroddsen, Fjölmali, Reykjavík: Bókaútgáfa Menningarsjóðs, 1967. 


\section{Höfundur og höfundarréttur}

Sumir fræðimenn halda pví fram að manninum sé eiginlegt að finnast höfundar eiga tilkall til eignarréttar á listaverkum sínum. Sagt er að í vissum ættbálkum, allt frá Inúítum og Indjánum í Ameríku til frumbyggja Ástralíu, pekkist að menn neiti að syngja söngva sem tilheyri öðrum ættflokkum eða söngvurum. Sagt er að gríska leikskáldið Aristofanes, á 5.-4. öld f.Kr., hafi neitað að viðurkenna mann sem sigurvegara í ljóðakeppni, pótt almenningur hefði valið hann, vegna pess að hann hefði ekki flutt eigin ljóð. Hugtakið ritstuldur (plagiat) er sagt koma fyrir í texta frá tímabilinu 40-104 e.Kr. (ekki er sagt hvar). Bann við endurritun mun standa á kínverskri bók frá pví fyrir 1068. ${ }^{7}$ Um írska munkinn Kólumkilla segir að hann hafi afritað í leyfisleysi saltara kennara síns, Finnians, árið 567 og Finnian kallað verknaðinn pjófnað. ${ }^{8}$ Aðrir fræðimenn leggja áherslu á að eiginlegar reglur um eignarrétt á textum hafi sprottið af upphafi prentlistar á 15. öld. Tímamót eru síðan gjarnan sett við bresk höfundarréttarlög kennd við Önnu drottningu Stuart, sett 1710.9 Svo próaðist höfundarréttarlöggjöf einstakra ríkja fram eftir 18. og 19. öld, og enn ein tímamót urðu árið 1886 með fyrsta fjölpjóðlega samkomulaginu um verndun höfundarréttar, svokölluðum Bernarsáttmála. ${ }^{10}$

Hvernig var pessu háttað á Íslandi? Allar lögbækur Íslendinga sem giltu á miðöldum, Grágás, Járnsíða og Jónsbók, eru til útgefnar með vönduðum atriðisorðaskrám, og bólar par hvergi á orðum sem tákna höfundarrétt. ${ }^{11}$ Aðeins á einum stað í fornritum okkar virðist höfundarhugtak stinga upp

7 Morten Rosenmeier, Ophavsret for begyndere: En bog til ikke-jurister, 2. útgáfa, København: Jurist- og Økonomforbundets Forlag, 2010, bls. 23-24.

8 Magnus Stray Vyrje, Opphavsrettens ABC, Otta: TANO, 1987, bls. 27; Páll Sigurðsson, Höfundaréttur, bls. 28-31.

9 YiJun Tian, Re-thinking Intellectual Property: The political economy of copyright protection in the digital era, London og New York: Routledge-Cavendish, 2009, bls. 13.

10 Henry Olsson, Upphovsrättslagstiftningen: En kommentar, Stockholm: Norstedts Juridik, 1996, bls. 22-23.

11 Grágás: Lagasafn íslenska pjódveldisins, Gunnar Karlsson, Kristján Sveinsson, Mörður Árnason sáu um útgáfuna, Reykjavík: Mál og menning, 1992, bls. 537; Fárnsíða og Kristinréttur Árna Porlákssonar, útgefendur Haraldur Bernharðsson, Magnús Lyngdal Magnússon, Már Jónsson, Reykjavík: Sögufélag, 2005, bls. 202; Fónsbók: Lögbók Íslendinga bver sampykkt var á albingi árið 1281 og endurnýjuð um miðja 14. öld en fyrst prentuð árið 1578, Már Jónsson tók saman, Reykjavík: Háskólaútgáfan, 2004, bls. 343-344. - Hér er aðeins vísað í blaðsíður par sem orðið böfundr og samsetningar með pað að fyrri lið ættu að koma í stafrófsröð; mér koma ekki í hug önnur leitarorð. 
kolli, en pað er í Fyrstu málfræðiritgerðinni frá 12. öld par sem stendur: „Skáld eru höfundar allrar rýni eða málsgreinar sem smiðir [smíðar] eða lögmenn laga. “12 Ég sé ekki betur en orðið höfundur sé hér haft í svipaðri merkingu og í íslensku nútímamáli. Annars er orðið oftast haft um dómara í miðaldanorrænu. ${ }^{13}$ Við sækjum pví ekki mikinn fróðleik um höfundarhugtakið á fyrstu öldum Íslandsbyggðar í tilfelli par sem orðið höfundur eða samsetningar með pví eru notaðar.

\section{Nýting óbundins máls}

Norrænir miðaldahöfundar nýttu sér hiklaust og umyrðalaust rit eldri höfunda, tóku efni upp úr peim og afrituðu pau, eða létu afrita, að pví er virðist stundum eins orðrétt og menn kunnu eða peim sýndist. Sem dæmi má taka sögur af Noregskonungum, til og með Heimskringlu, eins og Bjarni Aðalbjarnarson segir frá peim í formála að fyrsta bindi Heimskringluútgáfu sinnar. ${ }^{14}$ Oftast nota pessir höfundar eldri rit án pess að geta pess á nokkurn hátt. Flest eru ritin varðveitt án höfundarnafns, eins og algengast er um norrænar fornsögur.

Hvergi veit ég til að höfundur fornsögu hafi verið sakaður um ritstuld. Hafa höfundar litið svo á að sögur peirra væru oft næstum pví alveg eins og eldri sögur vegna pess að pær væru að lýsa sömu atburðum og sömu persónum? Að staðreyndirnar væru fyrir hendi í hinum sögulega veruleika og pví hlytu sannar sögur af honum að verða eins að pví leyti sem skipti máli? Pær væru einskis manns verk, hvað pá eign. Petta er auðvitað fjarstæða í okkar augum en kannski litu miðaldamenn öðruvísi á málið. Рað skýrir pó ekki allt. Líka má benda á að miðaldamenn áttu til að viðurkenna hiklaust og án nokkurrar réttlætingar að peir tækju upp úr ritum annarra höfunda, að peir notuðu ritin en ekki bara almannaeign af sönnum fróðleik sem væri að finna í peim. Má par nefna Hauk Erlendsson lögmann sem skrifaði eina gerð Landnámabókar og lauk henni með eftirmála par sem segir:

12 The First Grammatical Treatise: Introduction. Text. Notes. Translation. Vocabulary. Facsimiles, Hreinn Benediktsson sá um útgáfuna, University of Iceland Publications in Linguistics I, Reykjavík: Institute of Nordic Linguistics, 1972, bls. 224-226. Stafsetning textans er hér færð í nútímahorf.

13 Johan Fritzner, Ordbog over Det gamle norske Sprog II, Kristiania: Den norske Forlagsforening, 1891, bls. 175.

14 Bjarni Aðalbjarnarson, „Formáli.“ Snorri Sturluson, Heimskringla I, Íslenzk fornrit XXVI, Bjarni Aðalbjarnarson gaf út, Reykjavík: Hið íslenzka fornritafélag, 1941, bls. v-cxl, hér bls. ix-xix. 
Nú er yfir farit um landnám pau, er verit hafa á Íslandi, eptir pví sem fróðir menn hafa skrifat, fyrst Ari prestr hinn fróði Porgilsson ok Kolskeggr hinn vitri. En pessa bók ritaða 〈ek〉, Haukr Erlendsson, eptir peiri bók, sem ritat hafði herra Sturla logmaðr, hinn fróðasti maðr, ok eptir peiri bók annarri, er ritat hafði Styrmir hinn fróði, ok hafða ek pat ór hvárri, sem framar greindi, en mikill porri var pat, er pær sogðu eins báðar, ok pví er pat ekki at undra, pó 〈at〉 pessi Landnámabók sé lengri en nǫkur ǫnur. ${ }^{15}$

Hér er enginn efi um að Haukur telji sér heimilt að búa til bók úr bókum annarra. Spyrja má hvort pað eigi við hvort sem bækurnar sem tekið er úr eru eftir lifandi menn eða dauða. Báðir Landnámuhöfundarnir sem Haukur nefnir voru allir pegar hann skrifaði bók sína og eftirmála hennar. Sá yngri peirra, Sturla Pórðarson sagnaritari, lést árið 1284, og talið er einna líklegast að Hauksbók hafi verið lokið um tveimur áratugum síðar. ${ }^{16}$ Sturlubókartextinn var samkvæmt pessu langt innan við mörk höfundarréttar miðað við evrópskar reglur okkar tíma sem almennt setja hann við 50-70 ár frá dauða höfundar. ${ }^{17}$ Að sjálfsögðu er engin ástæða til að vænta pess að sömu reglur hafi gilt pá og nú um smávægileg ákvörðunarefni eins og tímalengd höfundarréttar; aðalatriðið er að hvergi í íslenskum miðaldatextum verður vart við hugmyndina um að frumleiki sé kostur á texta í óbundnu máli, hvað pá skylda. Með pví má segja að hugmyndin um höfundarrétt sé útilokuð.

\section{Kveðið til braglauna}

Hugmyndir manna um eignarrétt á bundnu máli voru að einhverju leyti aðrar. Alkunnugt er að skáld ortu kvæði um konunga og páðu laun fyrir, jafnvel langvarandi vist við hirð konunganna. Eftir pví sem best er vitað var slíkur lofkveðskapur farinn að tíðkast á norrænu málsvæði strax á

15 Íslendingabók. Landnámabók, Íslenzk fornrit I, Jakob Benediktsson gaf út, Reykjavík: Hið íslenzka fornritafélag, 1968, bls. 395, 397 (Hauksbók, 354. kap.).

16 Stefán Karlsson, Stafkrókar. Ritgerðir eftir Stefán Karlsson, gefnar út í tilefni af sjötugsafmcli hans, 2. desember 1998, ritstjóri Guðvarður Már Gunnlaugsson, Reykjavík: Stofnun Árna Magnússonar, 2000, bls. 303-308 („Aldur Hauksbókar“), hér bls. 308.

17 Henry Olsson, Upphovsrättslagstiftningen, bls. 20; Vef. Lagasafn. Ílensk lög 20. janúar 2017, útgáfa 146a, 43. grein. 
9. öld, og pannig ortu hirðskáld um konunga næstu fjórar aldir. ${ }^{18}$ Ekki munu vera til miklar heimildir um endurgjöld til skálda á fyrstu öldunum, enda væri peim lítið að treysta svo langur tími sem leið milli atburða og skráningartíma. En síðar kemur margt fram í sögum um laun fyrir skáldskap, pótt ekki verði fullyrt að pað sé allt sannleikanum samkvæmt. Má til dæmis nefna íslenska skáldið Gunnlaug Illugason ormstungu, titilpersónu Gunnlaugs sögu. Í Noregi fór hann á fund Eiríks jarls Hákonarsonar sem réði fyrir landinu ásamt bróður sínum á fyrstu fimmtán árum 11. aldar. Eirík móðgaði Gunnlaugur svo að landi hans varð að koma honum undan til Englands. Par flutti Gunnlaugur Aðalráði konungi kvæði og hlaut að launum skarlatsskikkju og hirðvist um veturinn. Síðan hélt hann til Írlands og flutti Sigtryggi konungi silkiskegg drápu. Konungur var óreyndur í starfinu og vildi helst launa honum með tveimur knörrum en féhirðir hans sagði pað of mikið; ,aðrir konungar gefa at bragarlaunum gripi góða, sverð góð eða gullhringa góða.“19 Pá lét konungur nægja að gefa skáldinu skarlatsklæði, kyrtil, skikkju og merkurpungan gullhring. İ Orkneyjum flutti Gunnlaugur Sigurði jarli kvæði, en jarl gaf honum silfurrekna breiðöxi og bauð honum að vera með sér. En Gunnlaugur hélt til Vestur-Gautlands í Svípjóð og flutti Sigurði jarli í Skörum kvæði. Um kvæðislaun er ekki annað sagt en að jarl launaði honum vel og bauð honum að vera með sér um veturinn. Síðar heimsótti Gunnlaugur Ólaf Svíakonung í Uppsölum og lenti par í harðri keppni við Hrafn Önundarson, pann sem síðar keppti við hann um Helgu Porsteinsdóttur fögru, um pað hvor fengi að flytja konungi kvæði sitt á undan og hvort kvæðið væri betra. Báðir hlutu góðar gjafir að skilnaði pegar peir fóru úr landi. Síðar hafði Gunnlaugur aftur veturvist með Aðalráði Englandskonungi og taldist pá enn hirðmaður hans. $^{20}$

Petta er auðvitað glæsimynd, dregin upp til að gera örlög Gunnlaugs ennpá átakanlegri en ella pegar pau dynja yfir. En benda má á fleiri sögur sem sýna að pað var siður að skáld hefðu framfæri af hirðskáldskap. Sighvatur Pórðarson kom, samkvæmt Ólafs sögu helga í Heimskringlu, til Noregs ungur maður á konungsárum Ólafs Haraldssonar, páði af honum gullhring fyrir kvæði og var síðan lengi með honum. Um skeið var

18 Vésteinn Ólason, „Dróttkvæði, Hirðkveðskapur og annað lof“, Íslensk bókmenntasaga I, bls. 201-203.

19 Borgfirðinga sqgur, Íslenzk fornrit III, Sigurður Nordal og Guðni Jónsson gáfu út, Reykjavík: Hið íslenzka fornritafélag, 1938, bls. 76 (8. kap.).

20 Borgfirðinga sogur, bls. 68-83 (6.-10. kap.). 
Sighvatur pó með Knúti ríka Sveinssyni, konungi Dana og Englendinga, sem gerði einnig kröfu til Noregs, páði gullhring af honum líka og orti um hann drápu. Síðar kemur fram að Sighvatur var vinur norska héraðshöfðingjans Erlings Skjálgssonar, sem var fyrst vinur en síðar andstæðingur Ólafs konungs. Sighvatur hafði pegið gjafir af Erlingi og orti um hann eftir að hann féll fyrir liðsmanni konungs. Pá átti Sighvatur enn eftir að yrkja erfikvæði um Ólaf konung og gerast hirðskáld Magnúsar konungs sonar hans og yrkja honum Bersöglisvísur. ${ }^{21}$

Svo að lengra sé haldið, fram á 13. öld, orti Snorri Sturluson kvæði um Hákon Fólkviðarson galin, jarl á Gautlandi. En jarlinn sendi „gjafir út á mót, sverð ok skjöld ok brynju“.22 Árið 1219 fór Snorri svo austur á Gautland og flutti kvæðið Andvöku um Kristínu Nikulásdóttur, ekkju jarlsins, og var kvæðið ort að bæn jarls. „Ok tók hon sæmiliga við Snorra ok veitti honum margar gjafir sæmiligar. Hon gaf honum merki pat, er átt hafði Eiríkr Svíakonungr Knútsson.“23 Í sömu ferð orti Snorri tvö kvæði um Skúla jarl Bárðarson, sem fór pá nánast með konungsvald í Noregi sökum æsku Hákonar konungs Hákonarsonar. Pá páði Snorri að launum haffært skip og fimmtán stórgjafir. ${ }^{24}$ Рað hljóta að vera hæstu skáldalaun sem sagt er frá í heimildum. En pess verður að gæta að Skúli jarl var að leggja drög að pví að Snorri kæmi Íslandi undir krúnu konungs, og má pví hugsanlega líta á skáldalaunin öðrum præði sem mútur.

Eitt peirra íslensku skálda sem síðast reyndu að vinna sér álit í hirð Noregskonungs með kveðskap var Sturla sagnaritari Pórðarson. Hann fór til Noregs árið 1263 og lenti í leiðangri með Magnúsi konungi lagabæti. Konungur var pá eitthvað fúll við Sturlu, af ópekktum ástæðum, og tók ekki undir kveðju hans. En drottning, sem var með í för, fékk áhuga á Sturlu; hún réði pví að hann fékk að flytja kvæði um Magnús konung og lét í ljós álit sitt fyrst manna: „Pat ætla ek, at kvæðit sé vel ort.“ Konungur efaðist um að hún kynni gerla að heyra pað, enda var drottning af dönskum

21 Snorri Sturluson, Heimskringla II, Íslenzk fornrit XXVII, Bjarni Aðalbjarnarson gaf út, Reykjavík: Hið íslenzka fornritafélag, 1945, bls. 54-318 (Óláfs saga ins helga, 43.-176. kap.); Snorri Sturluson, Heimskringla III, Íslenzk fornrit XXVIII, Bjarni Aðalbjarnarson gaf út, Reykjavík: Hið íslenzka fornritafélag, 1951, bls. 20-31 (Magnúss saga ins góða, 9.-16. kap.).

22 Sturlunga saga I, Jón Jóhannesson, Magnús Finnbogason og Kristján Eldjárn sáu um útgáfuna, Reykjavík: Sturlunguútgáfan, 1946, bls. 269 (Íslendinga saga, 34. kap.).

23 Sama rit I, bls. 271-272 (Íslendinga saga, 35. kap.).

24 Sama rit I, bls. 278 (Íslendinga saga, 38. kap.). 
uppruna og varla vel að sér í vestnorrænu skáldamáli. Konungur lét hins vegar ótvírætt í ljós að hann hefði ekki vit á efninu pví að hann sagði eftir að hann hafði hlustað á Sturlu flytja kvæðið: „Spurt hefi ek, at Sturla kann at yrkja. “25 Að kvöldi sama dags lét konungur kalla á Sturlu og bað hann að kveða kvæðið sem hann hefði ort um föður Magnúsar, Hákon konung, sem var pá í síðustu herferð sinni vestur í Orkneyjum. Pegar Sturla hafði gert pað er haft eftir konungi: „Pat ætla ek, at pú kveðir betr en páfinn.“ Sturla varð síðar hirðmaður konungs. „Hann orti mörg kvæði um Magnús konung ok pá margfalda sæmð par fyrir.“26

Skáldskapur var pannig eins konar farareyrir Íslendinga um aldir. Konungar og jarlar voru sýnilega drýgstu kaupendur hans. En fyrir kom að ort væri um ótignari menn. Íslendingurinn Ásu-Pórður orti pannig á konungsárum Eysteins Magnússonar, 1103-1130, um lendan mann norskan, Vi̊xunn Jónsson, sem hafði reynst honum óvinveittur. Víðkunnur gaf gullhring fyrir, ekki er tekið fram hve pungan, en Pórður afpakkaði gjöfina og kaus frekar vináttu Víðkunns. ${ }^{27}$

Var líka markaður fyrir skáldskap á Íslandi? Örfá dæmi eru um að skáld yrktu lofkvæði um Íslendinga. Ari Porgeirsson, faðir Guðmundar biskups góða, féll í ófriði austur í Noregi árið 1166, og orti Porvarður bróðir hans pá erfiflokk eftir hann. ${ }^{28}$ Ólafur Pórðarson hvítaskáld orti drápu um Porlák biskup helga og fór suður í Skálholt á föstunni 1237 undir pví yfirskyni að hann vildi flytja drápuna. Erindið var pó í rauninni að hitta Snorra Sturluson, föðurbróður Ólafs, vegna ýfinga innan Sturlungafjölskyldunnar, en Snorri hafði pá vist á Reykjum í Ölfusi. ${ }^{29}$ Í Pórðar sögu kakala í Sturlungu eru tilfærðar nokkrar vísur úr drápu sem Skáld-Hallur nokkur orti um Brand Kolbeinsson, höfðingja Skagfirðinga. Par segir frá síðasta bardaga Brands par sem hann féll, í Haugsnesi 1246. ${ }^{30}$ Pá segir í Sturlungu að Sturla Pórðarson hafi ort erfidrápu, Porgilsdrápu, um Porgils skarða Böðvarsson, bróðurson sinn. Eru birt í Sturlungu prjú erindi úr kvæðinu. ${ }^{31}$ Pessi íslensku kvæði eru pví sýnilega öll ort eftir dauða

25 Sama rit II, bls. 233 (Sturlu páttr, 2. kap.).

26 Sama rit II, bls. 234-235 (Sturlu páttr, 2. kap.).

27 Morkinskinna II, Íslenzk fornrit XXIV, Ármann Jakobsson og Pórður Ingi Guðjónsson gáfu út, Reykjavík: Hið íslenzka fornritafélag, 2011, bls. 108-109 (75. kap.).

28 Sturlunga saga I, bls. 121 (Prestssaga Guðmundar góða, 2. kap.).

29 Sama rit I, bls. 402 (Íslendinga saga, 121. kap.).

30 Sama rit II, bls. 73-74, 76-79 (Íslendinga saga, 41.-42. kap.).

31 Sama rit I, 517-518 (Íslendinga saga, 189. kap.); II, 113-114 (Porgils saga skarða, 6. kap.). 
söguhetjunnar; engar heimildir eru um að neinn höfundanna hafi fengið pau launuð og sum hafa væntanlega verið persónulegar tjáningar á sorg og söknuði, pegar ort var um náin skyldmenni. Eina skáldið sem ég pekki heimild um að hafi hlotið skáldskaparlaun á Íslandi á miðöldum var Egill Skalla-Grímsson, pegar hann fór priggja vetra gamall í leyfisleysi í veislu til Yngvars afa síns á Álftanesi á Mýrum. Hann kvað par dróttkvæða vísu, að sögn Egils sögu, og fékk að launum prjá kuðunga og andaregg. ${ }^{32}$ Hér er sjálfsagt verið að grínast án pess að í pví purfi að felast skop um bragarlaun. Egill átti eftir að verða pekkt hirðskáld, og hér er sýnt að krókur hans hafi snemma beygst til pess sem verða vildi.

\section{Sögumenn}

Ekki er hægt að ímynda sér annað en að mikið hafi verið gert að pví að segja sögur á Íslandi - og væntanlega í Noregi - fyrir ritöld og lengur. Um pað er samt fremur fátt sagt í sögum. Pví er einkar dýrmæt heimild páttur sem hefur verið gefinn út með titlinum „Íslendings páttur sögufróða“. Hann er til í tveimur gerðum; önnur er 44. kafli Morkinskinnu; hin er varðveitt sem sérstakt rit, kölluð hin sjálfstæða gerð par sem hún er gefin út í ellefta bindi Íslenskra fornrita. Í Morkinskinnugerðinni er hinn sögufróði Íslendingur ekki nafngreindur, aðeins sagður „einn íslenzkr maðr, ungr ok fráligr", en í hinni gerðinni er hann nefndur Porsteinn og sagður hafa alist upp í Austfjörðum. En sameiginlegt efni páttanna er pað að Íslendingurinn kemur til hirðar Haralds konungs Sigurðarsonar, sem réði fyrir Noregi á árunum 1046 til 1066, og vildi fá hirðvist. Konungur spurði hvað hann kynni og sagðist hann kunna sögur. Pá var hann ráðinn til að skemmta með sagnaflutningi, og gekk pað svo vel að hirðmenn gáfu honum klæði en konungur vopn. Undir jól fer Íslendingur að verða óglaður og segir aðspurður að nú kunni hann ekki fleiri sögur nema af útferð konungs sjálfs, en Haraldur hafði verið í Miklagarði. Pá sögu porði hann hins vegar ekki að segja í viðurvist konungs. Konungur sagði að pað væri sú saga sem sig langaði mest til að heyra og bað Íslendinginn að byrja hana á fyrsta jóladag og kvaðst mundu stilla svo til að hún entist út jólin. Pað gekk allt eftir, en konungur lét aldrei neitt uppi um hvernig sér líkaði. Á prettánda degi jóla lauk svo sögunni og konungur sagði loks að hún væri hvergi verri en efni stæðu til. Hann spurði sögumann hver hefði kennt honum söguna, en hann

32 Egils saga Skalla-Grimssonar, Íslenzk fornrit II, Sigurður Nordal gaf út, Reykjavík: Hið íslenzka fornritafélag, 1933, bls. 80-82 (31. kap.). 
svaraði pví að hann hefði farið hvert sumar á ping og hlustað á Halldór Snorrason, son Snorra goða, segja hana, en Halldór hafði verið með konungi í Miklagarði. Konungur bauð sögumanni að vera með sér framvegis en gaf honum jafnframt „góðan kaupeyri“. Í Morkinskinnugerðinni segir að hann hafi orðið proskamaður en í hinni að hann hafi farið ,jafnan landa í milli ok var lọngum með konungi“. ${ }^{33}$ Hér er traust heimild um að sögur hafi verið sagðar á pingum á Íslandi, án pess að ástæða sé til að halda að Halldór Snorrason hafi gert pað í atvinnuskyni. En við hirð konungs var rúm fyrir atvinnusögumann sem páði laun og gjafir fyrir sögur sínar. Pótt auðvitað sé ekki hægt að trúa sögunni bókstaflega er par óneitanlega athyglisverð vísbending um að pað sé talið komið undir innihaldi sögunnar, efnislegum veruleika að baki henni, hve löng hún sé, úr pví að konungur gat skipt henni fyrirfram upp í hæfilega langa dagskammta til að hún fyllti jólin nákvæmlega.

Eftir að kemur fram á ritöld og tekið er að skrá sögur á skinn fjölgar varðveittum vitnisburðum um sögumenn. Frá áratugunum í kringum aldamótin 1200 eru tvær heimildir, væntanlega hvor annarri óháðar, um að Íslendingar séu taldir sérstaklega miklir sagnamenn á Norðurlöndum. Önnur er eftir norska Noregssöguhöfundinn Theodoricus sem segir í inngangi að konungasögu sinni: „Ég taldi pað ómaksinsvert [...] að rita í stuttu máli petta smáræði, eins nákvæmlega og mér er unnt að fregna, frá peim sem taldir eru fróðastir og við köllum Íslendinga, en peir varðveita í sínum gömlu kvæðum frásagnir um hina fornu konunga Noregs. “34 Hin heimildin er Danasaga Saxo par sem segir í inngangi að Íslendingar noti „hverja stund af lífi sínu til að leggja stund á fróðleik um afrek annarra. [...] Peir hafa mikla ánægju af pví að pekkja og fræða um sögur allra pjóða, pví í augum peirra er alveg eins göfugt að lýsa dáðum annarra eins og að drýgja sínar eigin." Verulegan hluta af verki sínu segir hann reistan á frásögnum peirra. Seinna í riti Saxo kemur við sögu Arnaldur Íslendingur (Arnoldus Thylensis á latínu höfundar) sem var í fylgdarliði Absalons erkibiskups,

33 Morkinskinna I, Íslenzk fornrit XXIII, Ármann Jakobsson og Pórður Ingi Guðjónsson gáfu út, Reykjavík: Hið íslenzka fornritafélag, 2011, bls. 235-237; Austfirðinga sqgur, Íslenzk fornrit XI, Jón Jóhannesson gaf út, Reykjavík: Hið íslenzka fornritafélag, 1950, bls. 333-336, sbr. cxii-cxiv.

34 Pjóðrekur munkur, Sagan um bina fornu konunga Noregs ásamt Íslandskaflanum úr Historia Norwegiae, Guðmundur J. Guðmundsson pýddi, Selfossi: Sæmundur, 2016, bls. 25 . 
vinnuveitanda Saxo sjálfs, og hafði erkibiskup hann með sér í ferðum til að skemmta með sögum. ${ }^{35}$

Um petta leyti voru Íslendingar pegar farnir að færa pessa sérgrein sína yfir á ritlistarsviðið. Eitthvert fyrsta sagnarit okkar, Íslendingabók, skrifuð á milli 1122 og 1133, var pantað: „Íslendingabók gørða ek fyrst byskupum órum, Porláki ok Katli [...]“" segir í inngangi hennar en lokaorðin votta hver pessi „ek“ sé: „en ek heitik Ari““. ${ }^{36}$ Síðan lagðist sá siður mjög af að höfundar merktu sér rit í óbundnu máli. Leif er af pví í handritum Landnámabókar par sem segir, áður en kemur að landnámi í Húsavík eystra: „Nú hefir Kolskeggr fyrir sagt heðan frá um landnám.“37 En ekki er sagt hver hafði sagt fyrir pangað til.

Ekki síðar en á konungsárum Sverris Sigurðssonar í Noregi (11841202) tóku Noregskonungar upp pann sið að panta skráðar sögur um sig og forvera sína. Í formála Sverris sögu segir: „er pat upphaf bókarinnar er ritat er eftir peiri bók er fyrst ritaði Karl ábóti Jónsson, en yfir sat sjálfr Sverrir konungr ok réð fyrir hvat rita skyldi; er sú frásọgn eigi langt fram komin. “38 Jafnan hefur verið haft fyrir satt að pessi Karl sé Karl Jónsson sem var kjörinn ábóti á Pingeyrum árið 1169 en fór utan 1185, kom heim 1188 og lést $1213 .{ }^{39}$ Síðan fer litlum sögum af pví að Noregskonungar kaupi menn til ritstarfa pangað til Magnús Hákonarson lagabætir (12631280) ræður Sturlu Pórðarson til ritstarfa. Í Sturlu pætti Sturlungu segir að meðan Sturla var í Noregi og eftir að Magnús hafði tekið hann í sátt „hafði konungr hann mjök við ráðagerðir sínar ok skipaði honum pann vanda at setja saman sögu Hákonar konungs, föður síns, eftir sjálfs hans ráði ok inna vitrustu manna forsögn.“ Og litlu síðar: „Pá setti hann saman sögu Magnúss konungs eftir bréfum ok sjálfs hans ráði. “40 Vafalaust hefur Sturla verið á launum, að minnsta kosti á ríflegu framfæri í konungsgarði, við pessi verk. En hvergi mun koma fram að hann hafi talist hafa eignarrétt á sögunum eða nokkurs annars manns á pöntuðum sögum.

35 Gunnar Karlsson, Goðamenning: Staða og ábrif goðorðsmanna í pjóðveldi Íslendinga, Reykjavík: Heimskringla, 2004, bls. 441-442. Tilvitnun býdd par.

36 Íslendingabók. Landnámabók, bls. 3 (Prologus), 28 (Ættartala).

37 Sama rit, bls. 302 (Sturlubók, 287. kap.; Hauksbók, 248. kap.).

38 Sverris saga, Íslenzk fornrit XXX, Porleifur Hauksson gaf út, Reykjavík: Hið íslenzka fornritafélag, 2007, bls. 3 (Prologus).

39 Sverrir Tómasson, „Veraldleg sagnaritun 1120-1400, Konungasögur“, Íslensk bókmenntasaga I, bls. 392.

40 Sturlunga saga II, bls. 234-235 (Sturlu páttr, 2. kap.). 


\section{Ritstuldir og endurnýting kveðskapar}

Úr pví að lofkvæði töldust verðmæti sem hægt var að piggja greiðslur fyrir, og mikið pótti komið undir bví að pau væru vel ort, má búast við dæmum um að eitt skáld hafi nælt í kveðskap frá öðru. Sá norræni miðaldamaður sem oftast hefur verið vændur um petta er norskt hirðskáld á 10. öld, Eyvindur Finnsson, sem gengur undir viðurnefninu skáldaspillir í konungasögum. Par eru Eyvindi eignuð kvæðin „Hákonarmál“ um Hákon Noregskonung Aðalsteinsfóstra (21 erindi), „Háleygjatal“ um ætt Hlaðajarla í Noregi (13 erindi) og 14 lausavísur. ${ }^{41}$ Pví hefur lengi verið haldið fram að viðurnefni sitt hafi Eyvindur fengið vegna pess að hann hafi pótt stæla kvæði annarra skálda. Í bókmenntasögu sinni rekur Finnur Jónsson pessa skýringu til Jóns Sigurðssonar, en bætir við að „raunar margir á undan honum" hafi haldið pessu fram. ${ }^{42}$ En tilefni pessarar túlkunar er sjálfsagt pað sem stendur í Fagurskinnu um hvernig Eyvindur orti um konung sinn, Hákon Aðalsteinsfóstra, eftir að hann hafði látist af sári sem hann fékk í orustu við Gunnhildarsyni, syni Eiríks konungs blóðaxar og Gunnhildar drottningar hans. Fagurskinna segir að Hákon

fylkði liði sínu ok lét hirðmenn ok boðsmenn alla saman, sem Eyvindr segir í kvæði pví, er hann orti eptir fall Hákonar, ok setti hann pat eptir pví sem Gunnhildr hafði látit yrkja um Eirík sem Óðinn byði hónum heim til Valhallar, ok segir hann marga atburði í kvæðinu frá orrostunni, ok hefir svá:

$$
\begin{aligned}
& \text { Gondul ok Skogul } \\
& \text { sendi Gautatýr } \\
& \text { at kjósa um konunga, } \\
& \text { hverr Yngva æettar } \\
& \text { skyldi með Óðni fara } \\
& \text { í Valhǫll at vesa. }{ }^{43}
\end{aligned}
$$

41 Poetry from the Kings' Sagas I. Part 1, Diana Whaley gaf út, Skaldic Poetry of the Scandinavian Middle Ages I, Turnhout: Brepols, 2012, bls. 171-235. Ummæli fræðimanna um Eyvind skáldaspilli eru flest fundin eftir tilvísunum pessa rits.

42 Finnur Jónsson, Den oldnorske og oldislandske Litteraturs Historie I, København: G.E.C. Gads Forlag, 1920, bls. 456, „forresten mange för ham“.

43 Ágrip af Nóregskonunga sogum. Fagrskinna - Nóregs konunga tal, Íslenzk fornrit XXIX, Bjarni Einarsson gaf út, Reykjavík: Hið íslenzka fornritafélag, 1985, bls. 86 (12. kap.). Gondul og Skegul eru valkyrjuheiti, segir útgefandi neðanmáls en Gautatýr Oðinn. 
Vísurnar eftir ónefnt skáld Gunnhildar eru líka birtar í Fagurskinnu. Рað sem par var talið sameiginlegt með kveðskap Eyvindar mun vera lýsing á viðbúnaði Óðins við komu Eiríks konungs blóðaxar til Valhallar:

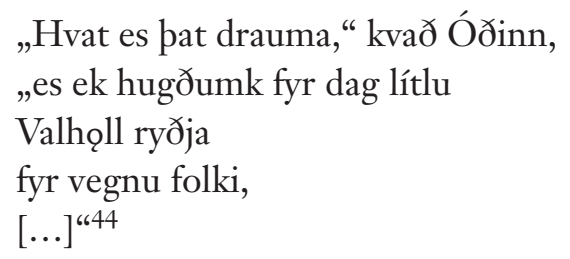

Ludvig Holm-Olsen staðhæfði að pað væri petta svipmót vísnanna í Fagurskinnu, og athugasemd sögunnar um pað, sem hefði leitt til túlkunarinnar á viðurnefni Eyvindar. Sú afstaða hans stafaði pó ekki af pví að hann hefði haft neitt á móti Eyvindi: hann lýkur máli sínu á að skrifa: „Samtîð hans gaf honum viðurnefnið skáldaspillir, viðurnefni sem síðari tíma fólk mun aldrei geta sætt sig við.“45

Раð eina sem er sameiginlegt kvæðunum er að Óðinn býr sig undir að taka við konungunum dauðum. En síðan hafa fræðimenn eðlilega fundið ýmislegt svipað með kvæðum Eyvindar og annarra skálda, og er of langt að rekja pað hér. Pótt vant sé um að dæma finnst mér ekki nógu sannfærandi að petta hafi nægt til að gefa pví skáldinu sem síðar orti niðrandi viðurnefni. Ummæli Fagurskinnu kunna að vera tilraun til að skýra viðurnefni Eyvindar, og síðan sér tilviljunin um að fleira í kveðskap Eyvindar megi eigna fyrirmynd annarra skálda.

Ekki hafa heldur allir verið sammála um pessa skýringu á viðurnefninu skáldaspillir. Stungið hefur verið upp á að -spillir sé af sömu rót og spillôn í gotnesku sem merki að „segja frá“ og spjall í íslensku. Orðið skáld merki upphaflega „söngur“, pannig að skáldaspillir merki kvœðamaður. ${ }^{46}$ Aðrir

44 Sama rit, bls. 77. Vísan er einnig í Snorra-Eddu og par sögð vera úr Eiríksmálum. Snorri Sturluson, Uppsala-Edda: Uppsalahandritið DG 11 4to, Heimir Pálsson sá um útgáfuna, Reykjavík og Reykholti: Opna og Snorrastofa, 2013, bls. 229. Par er fyrsta línan „Hvað er pað drauma, Óðinn,“ og segir útgefandi neðanmáls að pannig sé í öllum Edduhandritum.

45 Ludvig Holm-Olsen, „Øyvind Skaldaspiller“, Edda LIII/1953, 145-165, hér bls. 152, 165. „Hans samtid gav ham tilnavnet skáldaspillir, skaldeforderveren, et tilnavn som ettertiden aldri vil kunne forsone seg med.“

46 Elis Wadstein, „Bidrag till tolkning ock belysning av skalde- ock Edda-dikter“, Arkiv för nordisk filologi XI/1895, bls. 64-92, hér bls. 88-90. 
hafa haldið fram eldri skýringunni pótt pá greindi á um hvort viðurnefnið væri sanngjarnt ef pað væri skilið pannig. ${ }^{47}$ Á síðustu áratugum 20. aldar kom svo fram sú hugmynd, að Eyvindur hafi verið kallaður skáldaspillir af pví að hann hafi pótt kasta skugga á önnur skáld, væntanlega með snilld sinni. ${ }^{48}$ Eða eru skýringarnar komnar í hring? Í alpýðlegu norsku fræðsluriti um Eyvind frá 1976 segir um viðurnefni hans: „Lengi var betta viðurnefni túlkað sem „allra skálda bestur“““. 49

Niðurstaðan af pessum skoðunum fræðimanna er óhjákvæmilega sú að við vitum ekki hvers vegna Eyvindur var kallaður skáldaspillir. Viðurnefni hans sannar pví ekkert um fordæmingu víkingaaldarfólks á pví að líkja eftir kveðskap eldri skálda.

Par kemur að meira gagni saga um annan mann sem var kannski um kynslóð eldri en Eyvindur og líka Norðmaður, Auðun illskældu, hirðskáld Haralds konungs hárfagra. Aðeins hálf önnur varðveitt lausavísa er eignuð honum..$^{50}$ Frá Auðuni er fyrst sagt í Egils sögu Skalla-Grímssonar par sem fjallað er um hirð Haralds konungs hárfagra: „Af ǫllum hirðmǫnnum virði konungr mest skáld sín; peir skipuðu annat ondvegi. Peira sat innast Auðun illskælda; hann var elztr peira, ok hann hafði verit skáld Hálfdanar svarta, fǫður Haralds konungs. “51 Auðunn er ekki nefndur í elstu konungasögum sem fjalla pó um ævitíma hans. Í fljótu bragði kann viðurnefnið að virðast auðráðið, að illskcelda sé sá sem yrkir illa. Pannig virðist E.H. Lind hafa skilið pað í bók sinni um vestnorræn viðurnefni og pýðir sem „Fuskskalden“.52 En í svokallaðri Skáldasögu Haralds konungs hárfagra,

47 Magnus Olsen, „Fortjener Hákonarmál’s digter tilnavnet „skáldaspillir“?“, Til Gerbard Gran 9. december 1916 fra venner og elever, Kristiania: H. Aschehoug \& co. (W. Nygaard), 1916, bls. 1-9, hér bls. 1; Finnur Jónsson, Den oldnorske og oldislandske Litteraturs Historie I, bls. 457; Egils saga Skalla-Grimssonar, bls. 56-57 nm (Sigurður Nordal).

48 Heinrich Beck, „Eyvindr skáldaspillir Finnsson“, Reallexikon der Germanischen Altertumskunde VIII, Berlin og New York: de Gruyter, 1994, bls. 58; Edith Marold, „Eyvindr Finnsson skáldaspillir“, Medieval Scandinavia. An Encyclopedia, Phillip Pulsiano útgefandi, Kirsten Wolf meðútgefandi, New York og London: Garland, 1993, bls. 175-176, hér bls. 176.

49 Per Mehus, Øyvind Skaldaspiller: En helgelandsk bøvding og dikter for 1000 år siden, [S.1.]: Helgeland historielag. Småskrifter nr. 3, 1976, bls. 16. „Lenge ble dette tilnavnet tolket til „den fremste av alle skalder“."

50 Poetry from the Kings' Sagas I. Part 1, bls. 120-124.

51 Egils saga Skalla-Grimssonar, bls. 19 (8. kap.).

52 Erik Henrik Lind, Norsk-isländska personbinamn frän medeltiden: Samlade ock utgivna med förklaringar, Uppsala: A.-B. Lundequistska bokhandeln, 1920-1921, d. $178-179$. 
gamansögu um prjú hirðskáld konungs, sem er varðveitt í safnritinu Hauksbók, birtist önnur merking:

Haraldr konungr hárfagri réð fyri Noregi. Hann hafði með sér marga ágæta menn. Skáld prjú váru með konungi, Qlvir hnúfa ok Porbjǫrn hornklofi ok Auðunn illskælda. [...] Auðunn var pá kominn í sætt við konung fyri pat er hann tók stef ór drápu peirri er Úlfr Sebbason, frændi hans, hafði ort um Harald konung. Tók Auðunn par fyri auknefni en drápan Stolinstefju nafn, svá sem segir í sogu Úlfs Sebbasonar ok Kvígs jarls. ${ }^{53}$

Hvergi mun neitt vera til af sögu Úlfs Sebbasonar og Kvígs jarls. Finnur Jónsson, sem gaf Hauksbók út, par sem sagan er varðveitt, telur engan vafa á að Skáldasaga sé ung, varla eldri en frá lokum 13. aldar. ${ }^{54}$ Og sterk rök eru til að halda að Hauksbók sé skrifuð á fyrsta áratug 14. aldar. ${ }^{55}$ Í nýjustu dróttkvæðaútgáfunni, Poetry from the King's Sagas, er stungið upp á að Auðunn hafi kannski hlotið viðurnefni sitt af pví að hann hafi verið pekktur fyrir níðkveðskap, og er lausavísa hans sögð styðja pað. ${ }^{56}$ En pað skiptir okkur litlu máli hér vegna pess að frásögn Skáldasögu sýnir ótvírætt að pað gæti pótt í meira lagi ámælisvert á ritunartíma sögunnar að stela stefi úr kvæði. Nafnið Stolinstefja talar einkar skýru máli til nútímafólks - gæti verið eftir Tómas R. Einarsson - hvað sem líður raunverulegu tilefni pess að Auðunn hlaut viðurnefni sitt.

Enginn vafi getur verið á að Auðunn var talinn hafa stolið kveðskap eftir Úlf Sebbason. Hins vegar kemur fram í frásögninni að hann hafi verið í missætti við konung, ekki Úlf. Рað bendir til pess að misgerð hans hafi einkum verið við konung, glæpurinn felist í að flytja honum kvæði með stolnu stefi. Pá er misgerð Auðunar farin að minna á pað sem henti Pormóð Bersason, aðra söguhetju Fóstbræðra sögu. Hann ólst upp vestur við Ísafjarðardjúp og fékk mikinn áhuga á Pórdísi, dóttur Grímu ekkju í

53 Hauksbók: Udgiven efter de Arnamagneanske Håndskrifter no. 317, 544 og 675, 4º, samt forskellige papirshåndskrifter, København: Det kongelige nordiske OldskriftSelskab, 1892-1896, bls. 445. Stafsetning er stafrétt í útgáfunni en samræmd hér.

54 Finnur Jónsson, „Indledning“, Hauksbók: Udgiven efter de Arnamagneanske Håndskrifter no. 317, 544 og 675, $4^{\circ}$, samt forskellige papirshåndskrifter, København: Det kongelige nordiske Oldskrift-Selskab, 1892-1896, bls. lxxxvi-lxxxvii.

55 Stefán Karlsson, Stafkrókar, bls. 308 („Aldur Hauksbókar“).

56 Poetry from the Kings' Sagas I. Part 1, bls. 120. 
Ögri. Gríma bauðst til að gefa honum dóttur sína. En Pormóður sagðist ekki hafa skaplyndi til að kvongast og hélt pó áfram að venja komur sínar í Ögur.

Nú gerðist pað að Pormóður kom við í Arnardal á leið sinni út í Bolungarvík að sækja fisk. Par hitti hann aðra ekkjudóttur, Porbjörgu sem var kölluð Kolbrún af pví að hún var dökk yfirlitum. Pá ákvað Pormóður að spara sér ferðina út í Bolungarvík og bíða samferðarmanna sinna í Arnardal. Meðan Pormóður dvaldist par orti hann lofkvæði um Porbjörgu, kallaði pað Kolbrúnarvísur og flutti í heyranda hljóði. Móðir Porbjargar, Katla, gaf honum fingurgull að kvæðislaunum og nafnfesti pví að hún gaf honum líka nafn: Pormóður Kolbrúnarskáld.

Veturinn eftir fór Pormóður aftur að venja komur sínar í Ögur, en Pórdís tók honum fálega pví að hún hafði heyrt söguna um Kolbrúnarvísur. Pormóður kannaðist ekkert við pá sögu, sagðist hins vegar hafa ort lof um Pórdísi, sneri vísunum upp á hana og gaf henni kvæðið. Skömmu síðar birtist Kolbrún Pormóði í draumi og lagði á hann ópolandi augnverk sem létti ekki fyrr en hann hafði snúið kvæðinu á ný upp á Kolbrúnu og flutt pað pannig við mörg vitni. ${ }^{57}$

Hér er Pórdís í hliðstæðu hlutverki við konung í sögu Auðuns illskældu; peim var báðum boðið upp á áður notaðan kveðskap. En litlum sögum fer af viðbrögðum hennar eftir að Pormóður sneri vísunum upp á Porbjörgu kolbrúnu aftur. Pá hverfa pær báđar úr sögunni, Kolbrún og Pórdís. ${ }^{58}$ Samt er boðskapur sögunnar í Fóstbræðra sögu auðlesinn: ef karlmaður gefur konu kvæði (og væntanlega öfugt) missir hann eignarrétt sinn á kvæðinu í peim skilningi að hann má ekki gefa pað annarri konu, eins pótt skipt sé um nöfn.

\section{Kveðskapur og höfundar i sögum}

Kveðskapur er notaður öðruvísi í sögum en laust mál á pann hátt að oftast er tekið fram hver hafi ort. Í fyrsta priðjungi Heimskringlu, sögum um

57 Vestfirðinga segur, Íslenzk fornrit VI, Björn K. Pórólfsson og Guðni Jónsson gáfu út, Reykjavík: Hið íslenzka fornritafélag, 1943, bls. 161-177 (Fóstbrœðra saga, 9.-11. kap.).

58 Lesendur sem rámar í einkar fallega lýsingu á sambúð peirra Pormóðs og Pórdísar í Ögri og dætrum peirra tveimur munu hafa hana úr Gerplu Halldórs Kiljans Laxness par sem uppruni hennar er líklega á Gljúfrasteini í Mosfellsdal fremur en úr Fóstbræðra sögu. - Halldór Kiljan Laxness, Gerpla, Reykjavík: Helgafell, 1952, bls. 314-319 (36. kap.). 
Noregskonunga á undan Ólafi helga, eru til dæmis tilfærðar 193 vísur og vísubrot, allt niður í eina ljóðlínu. Af peim er 191 sögð vera eftir nafngreind skáld, flest alpekkt en ekki öll, og oftast er vísunum sýnilega ætlað að staðfesta frásögnina. Pær eru notaðar sem heimildir eins og Snorri Sturluson lýsti og ræddi af miklu viti í formálum að konungasögum sínum. ${ }^{59}$ Ein vísa er ekki höfundargreind en sögð vera úr níði Íslendinga um Harald Danakonung Gormsson og Birgi bryta hans, og eitt vísubrot er innleitt með orðunum „Pá var petta kveðit:“60

Í Íslendingasögum er sjaldan eða aldrei tiltækilegt sams konar heimildasafn í bundnu máli. Helst er slíkt til í sögum sem hafa skáld að aðalpersónum, og par er mestur hluti vísna eignaður söguhetjunni. Í Gunnlaugs sögu ormstungu eru 25 vísur, allar höfundargreindar. Gunnlaugi eru eignaðar 19 vísur (par af ein draumvísa föður hans, flutt eftir að Gunnlaugur var dauður), andstæðingi hans Hrafni Önundarsyni fjórar (líka ein dauðum), Pórði Kolbeinssyni í Hítarnesi ein og Porkatli Hallkelssyni, síðari manni Helgu fögru Porsteinsdóttur, ein. ${ }^{61}$

Í Íslendingasögum sem hafa ekki skáld að aðalpersónu er eðlilega minna um skáldskap. Í Brennu-Njáls sögu, texta sem er næstum átta sinnum lengri en Gunnlaugs saga, eru aðeins 34 vísur. Tilefni pess að birta vísurnar eru hér stórum fjölbreyttari en í sögunum sem eru nefndar hér á undan, og stundum er óljóst hvort sá sem flytur vísu yrkir hana sjálfur eða fer með gamlan kveðskap. Svanur bóndi á Svanshóli galdrar poku með pví að kasta fram kviðlingi, en ekki er ljóst hvort hann yrkir hann sjálfur. Gunnar á Hlíðarenda og Skarphéðinn Njálsson heyrast báðir kveða vísur dauðir. Dularfullur maður á gráum hesti spáir Njálsbrennu með pví að kveða vísu. Risinn í Lómagnúpi spáir í vísu hefndum eftir brennuna. Dularfullar konur á Katanesi á Skotlandi sjást vefa úr mannapörmum með vefstaði úr líkamspörtum og vopnum. Við verk sitt kveða pær ellefu vísur og spá með peim bardaga. Hér pjónar skáldskapurinn einkum pví hlutverki að skapa blæ og gefa frásögninni svip. En helmingur vísnanna í sögunni er eignaður einstökum, mennskum og lifandi höfundum. ${ }^{62}$

59 Snorri Sturluson, Heimskringla I, bls. 5 (Prologus); Snorri Sturluson, Heimskringla II, bls. 422 (Ór Óláfs sǫgu ins helga inni sérstǫku, Prologus).

60 Sama rit I, bls. 15-371 (Ynglinga saga, 5. kap. - Óláfs saga Tryggvasonar, 115. kap.). Óhöfundargreindu vísurnar eru á bls. 129 og 270. Lausavísur bindisins eru tölusettar 1-172, en vísur Hákonarmála, á bls. 193-197, eru tölusettar sérstaklega.

61 Borgfirðinga segur, bls. 63-107 (5.-13. kap.).

62 Brennu-Njáls saga, Íslenzk fornrit XII, Einar Ól. Sveinsson gaf út, Reykjavík: Hið íslenzka fornritafélag, 1954. Á bls. 38-460 (í 12.-157. kafla) eru 23 tölusettar lausavís- 
Í peim hlutum Sturlunga sögu sem hafa verið endurgerðir sem Íslendinga saga Sturlu Pórðarsonar eru rúmlega 90 vísur og vísnahlutar sem ætla má að hafi verið frumsamin par sem og pegar pau komu inn í söguna. Tæpur helmingur, um 40, er sagður eftir nafngreinda, mennska og lifandi höfunda, og álíka margar eru draumvísur eða vísur sem heyrast kveðnar par sem ekki sést til neinna flytjenda. Á annan tug vísna er innleiddur með orðum eins og: „Pá var petta kveðit“ eða „var par kveðin vísa sjá“. Ef hægt er að tala um að vísurnar hafi eitthvert sérstakt hlutverk í sögunni er pað einna helst að draga athygli að meginatburðum, til dæmis með pví að láta karla og konur - eða hrafna - birtist fólki í draumi og kveða óhugnanlegar vísur. ${ }^{63}$

Auðvitað finnum við engin merki um höfundarrétt í nútímaskilningi í pessum sagnasöfnum; engu að síður sýna pau að vísur eru tengdar höfundum sínum miklu nánar en laust mál. Í fleiri tilvikum en ekki pykir viðeigandi að taka fram hver hafi ort vísu ef vitnað er til hennar. Á pann hátt er kveðskapur álitinn meiri höfundareign en frásagnir í óbundnu máli.

\section{Vörn gegn skaðlegum skáldskap}

Formleg lög Íslendinga um kveðskap að fornu snúast um allt annað en höfundarrétt; pau stefna einkum að pví að vernda fólk fyrir skáldskap. Í Vígslóða Grágásar stendur petta:

115 UM SKÁLDSKAP. Hvortki á maður að yrkja um mann lof né löst. Skal-a [skal ekki] maður reiðast við fjórðungi vísu nema lastmæli sé í. Ef maður yrkir tvö orð [vísuorð, braglínur], en annar önnur tvö, og ráđa peir báđir samt [saman] um, og varðar skóggang [ævilanga útskúfun úr samfélagi] hvorumtveggja [K: ef löstur er í eða háðung]. En ef eigi er háðung í, pá varðar priggja marka útlegð [fébótum]. Nú yrkir maður fleira um, og varðar pað fjörbaugsgarð [priggja ára brottvísun úr landi] pótt eigi sé háoung í. Ef maður yrkir hálfa vísu um mann, pá er löstur er í eða háđung [K: eða lof pað er hann yrkir til háðungar], og varðar bað skóggang. Nú ef hann kveður eða kennir öðrum, og er pað pá önnur sök og varðar enn skóggang, enda varðar svo peim er nemur pann verka [skáldskap] og

ur, á bls. 454-458 (í 157. kafla) ellefu vísur vefkvenna á Katanesi á Skotlandi. Ekki eru taldar með 30 vísur á bls. 465-480 sem aðeins eru í einum flokki handrita og prentaðar sem Viðbætir sögunnar. Pær hafa sýnilega ekki tilheyrt henni frá upphafi.

63 Sturlunga saga I, bls. 241-533 (16.-200. kap.). 
reiðir [breiðir út] til háðungar manni. Sú reiðing varðar skóggang er til háðungar mest. [...] Skóggang varðar meðförin sem verkinn, og skiptir engu hvort fyrr er sótt, og skal við hin sömu gögn sækja bæði. Skóggang varðar pó að maður yrki um dauðan mann kristinn eða kveði pað er um hann er ort til lýta eða til háðungar, og fer svo sök sú sem vígsök.

Ef maður hefir orð pað í skáldskap er annar maður á vígt um [má drepa fyrir] [K: að hann sé ragur eða stroðinn [sorðinn]], enda hefni hann vígi eða áverkum, og skal sá pá um illmæli sækja til bjargar sér. Ef maður kveður níð um mann að Lögbergi, og varðar pað skóggang, enda fellur sá óheilagur [réttlaus] til pess alpingis er næst er eftir fyrir honum og peim mönnum er honum fylgja til [...]

Ef maður yrkir níð eða háðung um konung Svía eða Dana eða Norðmanna, og varðar pað skóggang og eiga húskarlar peirra sakirnar. En ef peir eru eigi hér staddir eða vilja peir eigi sækja, pá á sök sá er vill.

Ef maður yrkir mansöng [ástarkvæði] um konu, og varðar pað skóggang. Kona á sök ef hún er tvítug eða eldri. En ef hún er yngri, eða vill hún eigi sækja láta, pá á lögráđandi hennar sökina.

Ef maður kveður skáldskap til háðungar manni, pótt um annan mann sé ort, eða snýr hann á hönd honum nokkuru orði, og varðar skóggang, og skal svo sækja sem um skáldskap annan.

Ef maður yrkir víðáttuskáldskap, pá á hver maður pess kost er vill að dragast undir og stefna um, pótt kviður beri pað að hinn hafi eigi um pann ort er sækir um, en pað beri pó kviður að hann hafi ort, og varðar pó skóggang um víðáttuskáldskap. Рað er víðáttuskáldskapur er maður yrkir um engi mann einkum, enda fer pað pó um hérað innan, og varðar skóggang.

\section{UM SKÁLDSKAP AĐ SÆKJA. [...]}

Pó að eitt orð sé ort um mann, og fari pó helmingur saman eða lengra, og er pá kostur að sækja um. Svo er og pó að fjórir menn yrki helming vísu eða átta menn yrki alla vísu, og yrki eitt orð hver peirra, pá varðar pað skóggang öllum peim ef peir ráða allir saman um, og skal sækja sem um annan skáldskap. ${ }^{64}$ bók eru prentaðar innan hornklofa og merktar með K:. Önnur orð innan hornklofa eru flest úr orðaskýringum útgáfunnar. 
Ekki parf að koma á óvart pótt litlar móðganir pyrfti, að okkar mati, til pess að lögin hótuðu skóggangsrefsingu. Pannig eru refsilög Grágásar. Раð sem kemur á óvart er bannið við skáldskap sem ekki var í last eða háðung. Tvær tegundir af slíkum skáldskap eru nefndar í Grágásarköflunum sem eru birtir hér á undan. Annars vegar er loflegur kveðskapur sem er lengri en fjórðungur vísu, meira en tvö vísuorð, hins vegar mansöngvar um konur. Jenny Jochens fannst útilokað að ástarsöngvar, eins og mansöngvar voru á síðari tímum, hafi verið svo illa séðir að peir væru bannaðir með lögum; pví hlytu mansöngvar peir sem eru nefndir í Grágás að hafa verið klúrar vísur um ambáttir sem menn notuðu til kynlífs, enda getur orðið man merkt ambátt í fornu máli. ${ }^{65} \mathrm{Jafnvel}$ pótt svo væri ekki kann að vera að pað hafi pótt geta spillt orðspori kvenna ef bærist út að pær hefðu verið lofaðar í kvæði; pað gæfi í skyn ástarsamband á milli konunnar og skáldsins. Petta mun hafa vakað fyrir Einari Ólafi Sveinssyni pegar hann segir um mansöngskvæði að væri „við búið, að pau kæmu óorði á konuna“. ${ }^{66}$ En bæði fyrr og síðar hafa menn stungið upp á skýringu sem mér finnst mest sannfærandi, að bannið hafi verið sett til pess að koma í veg fyrir að stúlkur væru tældar með lofkvæðum. Feður og aðrir lögráðendur vildu helst ráđa pví hverjum stúlkur væru gefnar. ${ }^{67}$

Vandséðara er hvers vegna var sett bann við pví að ort væri og flutt opinberlega lof um fullorðna karlmenn. Gunnar Thoroddsen segir fátt um petta ákvæði nema að pað sé merkilegt en vitnar til bókmenntasögu Finns Jónssonar um að pað sé í rauninni sett til að hindra að menn yrki og breiði út ljóð sem séu lofleg á yfirborðinu en í rauninni háð. ${ }^{68}$ Pótt ekki sé pað tekið beinlínis fram í lögunum hefur væntanlega verið gert ráð fyrir að skáld sem fengi leyfi yrkisefnis síns til að kveða um hann væri par með undanpegið banninu, enda var pað siður að skáld bæðu konunga um að

65 Jenny Jochens, „From Libel to Lament: male manifestations of love in Old Norse“, From Sagas to Society: Comparative approaches to early Iceland, Gísli Pálsson gaf út, Enfield Lock: Hisarlik Press, 1992, bls. 247-264.

66 Einar Ól. Sveinsson, Ílenzkar bókmenntir ífornöld, Reykjavík: Almenna bókafélagið, 1962, bls. 88.

67 Lars Lönnroth, „Skirnismál och den fornisländska äktenskapsnormen“, Opuscula Septentrionalia: Festskrift til Ole Widding 10.10. 1977, Hafniæ: C.A. Reitzels boghandel, 1977, bls. 154-178, hér bls. 163; Bjørn Bandlien, Å finne den rette: Kjerlighet, individ og samfunn i norrøn middelalder, [S.1.]: Den Norske Historiske Forening, 2001, bls. 64-70; Gunnar Karlsson, Ástarsaga Íslendinga að fornu: Um 870-1300, Reykjavík: Mál og menning, 2013, bls. 118-119.

Gunnar Thoroddsen, Fjölmali, bls. 23, 25. 
hlýða á kvæði sín. En engar heimildir pekki ég um að skáld hafi talið sig purfa að fá leyfi til að yrkja um mann vísu. Einfaldasta skýringin á ákvæðinu er sú að hér sé verið að sporna sem afdráttarlausast við pví að menn köstuðu fram vísum sem fælu í sér last eða háð eða aðdróttanir án pess að hægt væri að sanna að svo væri. Ekkert mál var höfðað nema einhver teldi sneitt að sér.

Í lagatextanum er kviði, tylftarkviði eða dómi engin heimild veitt til að fella mál niður ef einhver hafði stefnt höfundi fyrir dóm. En freistandi er að halda að pannig hafi pó verið farið að; pessir aðilar hafi getað metið pað svo að málshöfðun væri ástæðulaus. En samkvæmt bókstaf laganna er hér dæmalaust eindregin vörn gegn mætti skáldskaparins. Og pá má varpa fram annarri og kannski langsóttari skýringu: að sá sem orti um mann, án leyfis, hafi pótt afla sér einhvers konar valdastöðu gagnvart honum. Раð virðist hafa verið stutt leið á milli skáldskapar og galdurs á heiðnum tíma. Raunar er kannski ekki laust við að pað séu algild sannindi að sá sem hælir manni á eftirminnilegan hátt geti öðlast einhvers konar vald yfir honum.

Sérstaklega torskilið er bannið við að yrkja níð eða háð um konunga Svía, Dana eða Norðmanna par sem gert er ráð fyrir að konungarnir kunni að eiga húskarla á Íslandi til að sækja mál gegn skáldunum. Jón Jóhannesson tengdi petta við frásögn í Jómsvíkinga sögu og Heimskringlu um að Haraldur Gormsson, konungur Dana og Norðmanna á síðari hluta 10. aldar, hafi hótað að herja til Íslands til að hefna níðs sem allir Íslendingar hefðu ort um hann. ${ }^{69}$ En sú frásögn er öll með helst til miklum ólíkindum til pess að auðvelt sé að ímynda sér að lagaákvæði geti verið viðbrögð við henni. Par segir að Danir hafi tekið allt fé af Íslendingum sem brutu skip sitt í Danmörku og Íslendingar brugðist við með pví að leiða í lög „at yrkja skyldi um Danakonung níðvísu fyrir nef hvert, er á var landinu [...]“. Раð virðist hafa náð fram að ganga, samkvæmt sögunni. Konungur ætlaði að sigla flota sínum til Íslands og hefna níðsins en skipaði fyrst „kunngum manni at fara í hamfǫrum til Íslands ok freista, hvat hann kynni segja honum. Sá fór í hvalslíki. “70 Par hitti hann fyrir landvættina sem prýða nú skjaldarmerki íslenska ríkisins. Hér er pess að gæta að húskarlar gátu verið aðrir en venjulegir vinnumenn. Í Noregi voru peir meðal annars nefndir sem fylgdarmenn konunga, hliðstæðir hirðmönnum en pó líklega oft

69 Jón Jóhannesson, Íslendinga saga I: Pjódveldisöld, Reykjavík: Almenna bókafélagið, 1956, bls. 266-268.

70 Snorri Sturluson, Heimskringla I, bls. 270-271 (Óláfs saga Tryggvasonar, 33. kap.). 
lægri að tign. Meðal annars segir í Hirðskrá Magnúsar konungs lagabætis: „Í fyrnskunni var sá siðr, at allir peir menn, sem konungi váru handgengnir eða sverðtakarar, pá váru allir kallaðir húskarlar, pó at síðan greindist nafnbœtr eptir sœmdum ok metorðum.“71 Líklegast finnst mér að orðið húskarl sé notað parna sem vítt hugtak um konungsmenn almennt, jafnvel alla frjálsa pegna konungs af karlkyni, og pá er bannið einkum hamla við pví að norrænir menn útlendir séu særðir með pví að yrkja níð um konunga peirra. Verið getur að óljós mörk hafi stundum verið á milli pess að maður teldist pegn norræns konungs eða Íslendingur, og pví hafi verið sett sú sérregla hér að sá ætti sök sem vildi ef húskarlar vildu ekki sækja. Hvers vegna gilti ákvæðið aðeins um norræna konunga? Vỉðar kemur fram að norrænu konungsríkin töldust einhvern veginn nálægari íslensku samfélagi en önnur ríki. Til dæmis kemur nokkrum sinnum fram í lögum að útlendir menn „af danskri tungu“ (par sem dönsk tunga er norræna) njóti annars og meiri réttar á Íslandi en aðrir útlendingar eða myndi á annan hátt félagslega heild. ${ }^{72}$

Ein óljós vísbending er til um að pað hafi pekkst í Noregi að setja lagaskorður við pví að yrkja lof um menn. Í fornlagasafni Norðmanna, Norges gamle Love, eru prentaðar slitrur af handriti að Frostapingslögum eldri, sem giltu í Prændalögum og fleiri norðlægum héruðum landsins. Par stendur: „En ef maðr yrkir um mann lof eða lost fiorðong vísu eða mæira. nema hinn vili s“. ${ }^{73}$ Framhaldið hefur verið skorið burt svo að ekki er hægt að sjá hver viðurlög voru við pessu, en hliðstætt ákvæði Grágásar, par sem lof og last er tekið saman og hvort tveggja sagt refsivert, bendir vissulega til að parna hafi staðið bann við lofkveðskap og pað hafi pví líka pekkst í Noregi.

Á árunum 1271-1273 var lögtekin í stað Grágásar lögbókin Járnsíða, að miklu leyti sniðin eftir norskum lögum en að lengdinni aðeins um níundi hluti af lengd Grágásar. Hún er pví ágripskennd og ónákvæm um margt. Par er ekkert almennt bann við yrkingum um menn en ákvæði um viðurlög við pví að yrkja mönnum til hnjóðs: „Nú ef maður yrkir um mann pað er

71 Johan Fritzner, Ordbog over Det gamle norske Sprog II, bls. 106-107; Norges gamle Love indtil 1387 II, R. Keyser og P. A. Munch sáu um útgáfuna, Lovgivningen under Kong Magnus Haakonssöns Regjeringstid fra 1263 til 1280, tilligemed et Supplement til förste Bind, Christiania: Chr. Gröndahl, 1848, bls. 416. Í tilvitnuninni er fylgt stafsetningu Fritzners en ekki Norges gamle Love pví að hún er svo framandleg.

72 Grágás, bls. 55, 70 (Erfðapáttur, 6. og 17. kap.), 239, 240, 281-282 (Vígslóði, 37., 38. og 121. kap.), 371 (Pingskapapáttur, 1. kap.), 457 (Baugatal, 2. kap.).

73 Norges gamle Love II, bls. 505. 
mönnum virðist til níðs eða háðungar fjórðung vísu eða lengra, pá skal hinn kveðja pings og kveða á pingi, en hinn færist undan með lýritareiði [eiði málsaðila og tveggja manna með honum] eða fari útlægur [í útlegð] og hverr penningur fjár hans nema jarðir."74 Í Jónsbók, sem var lögtekin 1281 í stað Járnsíðu og gilti síðan um aldir, er svipað ákvæði:

Ef maður yrkir um mann pað sem mönnum virðist til háðungar eður níðs fjórðungi lengra, pá skal sakaráberi kveðja pings og kveði á pingi en hinn færist undan með lýritareiði ef hann er fær til bess, ella gjaldi konungi fjórar merkur, en hinum rétt sinn eftir sex manna dómi. Nú kveða fleiri en einn fjórðungi lengra, pá sekist hver fyrir sig fullri sekt við konungdóminn og pann sem um var kveðið. Nú kveður maður skáldskap til háðungar manni pó að um annan sé ort eður snýr hann á hönd honum nokkuru orði, bæti peim eftir sex manna dómi en kóngi tvær merkur. Nú mál hvert er mælir maður við annan svo að honum horfi til hneyksla eður kennir manni hvinnsku eður fordæðu, og á hann eigi sjálfur sök á pví máli, pá er hann fjölmælismaður [meiðyrðamaður] nema hann hafi heimiliskviðarvitni [vitni sem staðfestir orðróm] á hendur hönum, pá skal hann sverja fyrir lýritareið, en ef hann missir heimiliskviðarvitnisins á pingi pá er hann sekur fjórum mörkum við konung en bæti hinum rétti sínum eftir sex manna dómi. [...] Engi maður sekist á pví orði sem færa má til góðs og ills. Jafnt sekist maður hvort sem mælt er við mann áheyranda eður afheyranda ef pað er vitnisfast. ${ }^{75}$

Hér, eins og líklega í fleiri málum, má greina pá stefnu að milda viðurlög. Samkvæmt Grágás og Járnsîðu var fjórðungur vísu saknæmur; samkvæmt Jónsbók slapp maður með að yrkja fjórðung en ekki pað sem lengra var. Í eldri bókunum áttu móðgandi ummæli í bundnu máli að leiða til algerrar útskúfunar, skóggangs og síðar útlegðar, og eignamissis. Í Jónsbók var útskúfun ekki nefnd og eignasviptingin færð niður í fjórar merkur til konungs (= 192 álnir eða um hálft annað kýrverð) auk fébóta til pess sem hafði verið særður.

Að sjálfsögðu var saknæmt líka að hæða fólk eða lasta opinberlega í óbundnu máli. En pegar kemur að pví verður strax óljósara hvort sakarefnið getur talist orðlist. Aðrar ástæður eru líka til að fjalla sérstaklega

74 Fárnsiða, bls. 88 (Mannhelgi, 25. kap.).

75 Fónsbók, bls. 118 (Mannhelgi, 27. kap.). 
um skáldskap hér. Við meiðyrðum í bundnu máli voru strangari viðurlög, venjulega skóggangur en fjörbaugsgarður við ærumeiðingum í óbundnu máli. ${ }^{76}$ Benda má líka á dæmi pess í sögum að last eða háð teljist ekki fullgert fyrr en pað sé komið í bundið mál. Svo að eitt dæmi sé tekið segir Brennu-Njáls saga frá orðillum förukonum sem fóru frá Bergpórshvoli að Hlíðarenda og sögðu par frá tíðindum. Ekkert skorti á orðlist peirra; pær sögðu til dæmis að Njáll bóndi hefði stritast við að sitja. Hallgerður húsfreyja lét sitt ekki eftir liggja heldur og stakk upp á að Njáll væri kallaður karl hinn skegglausi en synir hans taðskegglingar af pví að peir létu aka skarni á hóla. En pað nægði ekki, pví að Hallgerður bætti pví við að Sigmundur, frændi Gunnars, skyldi kveða „um nokkut [...], ok lát oss njóta pess er pú ert skáld“. ${ }^{77}$ Pá fyrst voru meiðyrðin fullgerð.

\section{Loksins böfundarréttur}

Hér að framan hefur komið fram að skáldskapur taldist til verðmæta á Íslandi á miðöldum. Fyrir hann var goldið, og ámælisvert pótti að gera annars skáldskap að sínum eigin. Skáldskap var hægt að gefa, og laut hann pá sömu reglum og önnur verðmæti; hefði maður gefið einum kvæði sitt var ekki heiðarlegt að gefa pað öðrum. Væri vitnað til skáldskapar annars manns í texta var viðeigandi að geta höfundar. Skáldskapur var líka vopn sem hægt var að nota til að særa. Ekki eru nærri pví eins skýr merki um verðmæti frásagnartexta í óbundnu máli, en sköpun peirra krafðist óhjákvæmilega vinnu, og pannig hlutu peir að geta orðið verðmæti, einkum ef halda purfti höfundi textans uppi meðan á vinnunni stóð.

Varla telst pó neitt af pessu höfundarréttur í okkar ströngustu merkingu. Hvenær verður hann pá til á Íslandi? Stutta svarið við pví er að lög um rithöfundarétt og prentrétt voru sett af Alpingi, staðfest af konungi árið 1905 og gengu í gildi 1. janúar 1906. Pau fylla átta blaðsíður í Stjórnartiððindum, en meginatriðið er í fyrstu grein:

Höfundur hver hefur eignarrjett á pví, er hann hefur samið. - Hann hefur pví, innan peirra takmarka, sem lög pessi setja, einkarjett á að birta og gefa út rit sín skrifuð, prentuð eða margfölduð á annan pvílíkan hátt, svo og til pess að sýna pau á leiksviði og lesa pau upp. Heimilt er pó að lesa upp rit, sem út hefur verið gefið, hafi rithöfundur eigi á titilblaði pess lagt bann við pví, og prátt fyrir slíkt bann

76 Gunnar Thoroddsen, Fjölmeeli, bls. 13.

77 Brennu-Njáls saga, bls. 113 (44. kap.). 
er upplestur leyfilegur, pegar liðin eru 5 ár frá pví, að ritið kom út í fyrsta sinn. Höfundur hefur og einkarjett á að gefa út ræður og fyrirlestra, er hann hefur haldið [...]. ${ }^{78}$

Frumvarpið til pessara laga var flutt sem stjórnarfrumvarp af Hannesi Hafstein ráðherra. Pví var vel tekið í pinginu og pað sampykkt mótatkvæðalaust í báðum deildum. ${ }^{79}$ Pegar ráðherra mælti fyrir frumvarpinu sagði hann að pað væri sniðið eftir dönskum lögum frá 1904. Varla yrði sagt að til væru nein lög á Íslandi sem vernduðu réttindi rithöfunda; minntist bó á tvær konunglegar tilskipanir um ritsmíðar, frá 1741 og 1828, en sagði vafasamt hvort pær hefðu gilt á Íslandi, auk pess sem pær væru „allsendis ófullnægjandi. Раð er pannig bannað að prenta upp aptur pað, sem gefið hefur verið út á prenti, en ekki bannað að taka handrit manna, og prenta pau að peim fornspurðum“ ${ }^{80}$ Mér virðist petta rétt hjá ráðherra. Tilskipanirnar snúast um að vernda prentaða texta en ekki höfundarrétt. ${ }^{81}$ Höfundarréttur komst fyrst verulega til umræðu á Íslandi árið 1889 pegar Jón Ólafsson ritstjóri flutti á Alpingi frumvarp til laga „um eignarrjett á sömdu máli“. Frumvarpið var sampykkt á pinginu og sent framkvæmdavaldinu til staðfestingar. ${ }^{82}$ En pví var synjað um konungsstaðfestingu, að tillögu danska Íslandsráðherrans, vegna ýmissa smáannmarka, auk pess sem pað væri í of mörgum atriðum öðruvísi en dönsk lög um sama efni. ${ }^{83}$ Eftir petta hvarf Jón Ólafsson af pingi pangað til 1905 pegar hann kom

78 Stjórnartíðindi fyrir Ísland 1905 A, Reykjavík: [Alpingi], 1905, bls. 116-131, hér bls. 116. Lögin eru birt bæði á íslensku og dönsku og fylla pví 16 blaðsíður í Stjórnartíðindum.

79 Alpingistíðindi 1905 B, Umreður íbádum pingdeildum og sameinuðu pingi, með yfirlitum, Reykjavík: [Alpingi], 1905-1906, d. 1531-1558.

80 Sama rit, d. 1531.

81 Lovsamling for Island, indeholdende Udvalg af de vigtigste eldre og nyere Love og Anordninger, Resolutioner, Instructioner og Reglementer, Althingsdomme og Vedtegter, Collegial-Breve, Fundatser og Gavebreve, samt andre Aktstykker, til Oplysning om Islands Retsforbold og Administration $i$ aldre og nyere Tider IX, útgefendur Oddgeir Stephensen og Jón Sigurðsson 1826-1831, Kjöbenhavn: Andr. Fred. Höst, 1860, bls. 297-298. Tilskipunin frá 1741 er ekki birt í Lovsamling en nefnd í tilskipuninni 1828 og pví bætt við neðanmáls að ekki finnist merki um að hún hafi verið send til Íslands eða öðlast gildi par.

82 Alpingistíðindi 1889, Reykjavík: [Alpingi], 1889. A: Yfirlit. Umreður í efri deild og sameinuðu pingi, d. 357, 401-402, 723; B: Umreður i neðri deild, d. 1110; C: Pingskjölin, bls. 495-497.

83 Björn Pórðarson, Alpingi og konungsvaldið: Lagasynjanir 1875-1904, Studia Islandica XI, Reykjavík: Leiftur, [1949], bls.100-101. 
pangað sem konungkjörinn pingmaður. Til peirrar stöðu hefur hann verið valinn af Hannesi Hafstein, og má pví geta sér pess til að Jón hafi staðið á bak við stjórnarfrumvarpið um höfundarrétt. Ekki er tóm til að kanna pað að pessu sinni, enda skiptir pað ekki miklu máli. Hinu má slá föstu að formlegur, lögbundinn höfundarréttur hafi ekki verið á dagskrá Íslendinga fyrr en í kringum aldamótin 1900.

Hér lítur út eins og tíðindalaust hafi verið á pessu sviði í sex hundruð sumur, frá lögtöku Jónsbókar til frumvarps Jóns Ólafssonar. Væntanlega stafar pað að einhverju leyti af ókunnugleika höfundar. Ég er einfaldlega ekki kominn lengra með petta mál. Hins vegar finnst mér engan veginn ólíklegt að íslensk miðaldasaga geti lagt eitthvað til málanna í réttarsögu orðlistar í heiminum. Óneitanlega átti orðlistin sérstakt blómaskeið á vesturnorrænu málsvæði á hámiðöldum, skeið sem leið undir lok á síðmiðöldum. Pess vegna er ekkert ólíklegt að par megi finna heimssögulegar nýjungar í réttarsögu orðlistar, hliðstæðar peim sem er drepið á í öðrum menningarheimum hér á undan.

\section{ÚTDRÁTTUR}

\section{Drög að réttarsögu orðlistar á Íslandi}

Í íslenskum miðaldalögum eru engin ákvæði um höfundarrétt. Höfundar nýttu sér hiklaust sögutexta annarra án leyfis, en skáld páðu laun fyrir að yrkja lofkvæði um konunga og sagnamenn fyrir að skemmta með sögum við hirð Noregskonungs. Sagnalist varð sérgrein Íslendinga, og Íslendingar voru ráðnir til að skrifa sögur norskra konunga. Ámælisvert pótti að nota kveðskap annars manns sem eigið verk. Talið hefur verið að tvö norsk skáld, Eyvindur skáldaspillir og Auðunn illskælda, hafi fengið viðurnefni sín af pví að peir hafi gert pað. Íslendingurinn Pormóður Kolbrúnarskáld orti lofkvæði um konu en sneri pví síðan upp á aðra konu og hlaut hefnd fyrir. Í íslenskum sögum er mikið um vísur og ólíkt lausu máli er oftar en ekki sagt hver hafi ort. Í íslenskum miðaldalögum er ekki aðeins bannað að yrkja last um menn heldur einnig lof. Hugsanlega hefur skáldskapur verið talinn gefa skáldinu vald yfir peim sem ort var um. En eiginlegur höfundarréttur kom ekki inn í íslensk lög fyrr en í upphafi 20. aldar.

Lykilorð: höfundarréttur, orðlist, ritlaun, ritstuldur, last, lof 


\section{A B S TRACT}

\section{Towards a legal history of verbal art in Iceland}

Medieval Icelandic law contains no provisions about copyright. Authors used without hesitation narrative texts by others, but poets were paid for composing laudatory poems about kings and narrators for telling stories at their courts. The art of storytelling became a speciality of Icelanders, who were also hired to write biographies of Norwegian kings. It was considered reprehensible to use the poetry of others as one's own work. Two Norwegian poets may have got the cognomens skáldaspillir (Destroyer of poets?) and illskelda (Bad or Evil poet?) for plagiarism. An Icelandic poet composed a laudatory poem about a woman but changed it to fit another one, receiving a bitter revenge. In Icelandic sagas stanzas occur frequently and, unlike borrowings in prose, their authors are usually named. In the medieval law of Iceland it is forbidden to compose about people not only derogatory but also laudatory poetry. Conceivably it has been considered to give the author some kind of power over the person who was the subject of the poetry. Proper copyright, though, does not occur in Icelandic law until the beginning of the twentieth century.

Keywords: copyright, verbal art, royalties, plagiarism, derogation, praise 